\title{
Steroid 17-Alpha-Hydroxylase/17,20 Lyase
}

National Cancer Institute

\section{Source}

National Cancer Institute. Steroid 17-Alpha-Hydroxylase/17,20 Lyase. NCI Thesaurus.

Code C40068.

Steroid 17-alpha-hydroxylase/17,20 lyase (508 aa, $57 \mathrm{kDa}$ ) is encoded by the human CYP17A1 gene. This protein is involved in steroid metabolism and sexual maturation. 